\title{
Nutrient Content, Active Compound, and Antibacterial Activity of Padina australis against Aeromonas hydropilla
}

\author{
Yuliana Salosso ${ }^{1, *}$, Siti Aisiah' ${ }^{2}$, Lumban Nauli Lumban Toruan ${ }^{3}$, Wesly Pasaribu ${ }^{1}$
}

Yuliana Salosso ${ }^{1}$, , Siti Aisiah ${ }^{2}$, Lumban Nauli Lumban Toruan ${ }^{3}$, Wesly Pasaribu' ${ }^{1}$

'Study Program of Aquaculture, Faculty of Fisheries and Marine Science, Nusa Cendana University, Kupang 85228, East Nusa Tenggara, INDONESIA.

${ }^{2}$ Department of Aquaculture, Lambung Mangkurat University, Banjarbaru 70711 South Kalimantan, INDONESIA.

${ }^{3}$ Study Program of Aquatic Resource Management, Faculty of Fisheries and Marine Science, Nusa Cendana University, Kupang 85228, East Nusa Tenggara, INDONESIA.

\section{Correspondence}

\section{Yuliana Salosso}

Department of Aquaculture, Faculty of Fisheries and Marine Science, Nusa Cendana University, Kupang 85228, East Nusa Tenggara, INDONESIA.

E-mail: yulimarasin@gmail.com

History

- Submission Date: 03-04-2020;

- Review completed: 19-04-2020;

- Accepted Date: 04-05-2020;

DOI : 10.5530/pj.2020.12.110

Article Available online http://www.phcogj.com/v12/i4

\section{Copyright}

(c) 2020 Phcogi.Com. This is an openaccess article distributed under the terms of the Creative Commons Attribution 4.0 International license.

\section{ABSTRACT}

Background: Padina australis is one of the brown macroalgae that possess several compounds that can be used for various medicinal properties. Objective: This study aims to analyze the nutrient content, active compounds, and antibacterial activity of Padina australis against Aeromonas hydropilla. Methods: The nutrient content and phytochemical composition of $P$. australis were examined in this study. The antibacterial effect was evaluated using the disc method against $A$. hydropilla. Results: The nutrient content of $P$. australis include $38.5 \%$ carbohydrate, $2.07 \%$ fat, $13.89 \%$ protein, $16.12 \%$ water, $33.34 \%$ ash, $8.54 \%$ total amino acid, and minerals (11.36\% calcium, $0.22 \%$ iron, and $1.81 \%$ potassium). Phytochemical analysis showed that $P$. australis contained phenols, tannin, flavonoid, and steroid. These compound may be responsible for inhibiting $A$. hydropilla, with an inhibition zone of $10.5 \mathrm{~mm}$ for water extract of $P$. australis and $10 \mathrm{~mm}$ for methanol extract $P$. australis. Conclusion: This study revealed that $P$. australis produced antibacterial effect against $A$. hydropilla which could be potential for further antimicrobial agent development.

Key words: Active compound, Antibacterial activity, Padina australis, Nutrient content.

\section{INTRODUCTION}

Macroalgae belong to thallophytes group or plant-like organisms which generally live in coastal areas. ${ }^{1-3}$ Macroalgae known as seaweed have significant economic value since they can be utilized as vegetables, traditional medicines, organic fertilizers, and livestock fed. ${ }^{1,3}$ Even the phytocoloid compounds extracted from macroalgae as agar, carrageenan, and alginate ${ }^{3}$, it can be used as raw materials of various industries, such as medicine, cosmetics, food, etc. Based on the pigment content, macroalgae are classified as green, red, and brown macroalgae., ${ }^{4,5}$ Several studies has been revealed that green, brown and red algae contain different metabolites and have much biological activity such as antiviral, antibacterial and antifungal. ${ }^{6}$

Padina australis is one of the brown macroalgae that possess numerous compounds that can be used for various properties, either nutrient content or active compounds. P. australis contains $1.05 \pm 0.09 \%$ protein, $0.58 \pm 0.01 \%$ fat, $8.78 \pm$ $0.80 \%$ carbohydrate, $87.25 \pm 0.86 \%$ water, $2.34 \pm$ $0.16 \%$ ash $^{7}$ and minerals as calcium, magnesium, potassium, sodium, copper, zinc, iron ${ }^{8}$ that enable to be developed as a food source and livestock fed. $P$. australis also contains various active compounds, such as steroid, terpenoid, flavonoid, tannin, and saponin $^{2,9,10}$ that can be used as medicinal drugs.

$P$. australis found abundantly in Indonesia sea and distributed almost all stony coasts including East Nusa Tenggara waters. According to Salosso and Jasmanindar ${ }^{11}$, brown macroalgae recorded in 5 sampling sites of Kupang Bay and distributed in all locations and sampling sites are P. australis with up to $80 \%$ occurrence frequency. Nevertheless, this species has not been maximally utilized yet by the community. ${ }^{10}$ To optimize the utilization of $P$. autralis collected from Kupang Bay, a study on nutrient content, active compounds, and antibacterial activity of $P$. australis were carried out in this paper.

\section{MATERIALS AND METHODS}

\section{P. australis collection}

P. australis were collected at the lowest tide in Kelapa Lima coastal waters, Kupang Bay, by searching along the coast and taking all encountered $P$. australis. They were put into a plastic bag, cleansed, recorded the fresh weight, air-dried, and then ready for further analyses.

\section{Chemical composition analysis}

Chemical composition analyses of $P$. australis include water, ash, protein, and fat content. ${ }^{12}$ Carbohydrate content was determined by difference as follows: $100 \%$ - (\% water $+\%$ fat $+\%$ protein $+\%$ ash $)$. Amino acid content was determined using a HighPerformance Liquid Chromatography (HPLC). Mineral analyses on calcium (Ca), potassium (K), and iron $(\mathrm{Fe})$ were assayed using Atomic Absorption Spectrophotometer (AAS).

\section{Phytochemical analysis of $P$. australis}

Phytochemical investigations of $P$. australis include alkaloid, saponin, flavonoid, tannin, terpenoid, and steroid. Alkaloid was examined using CulvenorFiztgerald method, saponin was analyzed using a foam test, tannin was analysed using $\mathrm{FeCl}$, and terpenoid and steroid was analyzed using the Lieberman-Burchard method. ${ }^{13}$ 


\section{P. australis extraction}

Water extraction was done by boiling $10 \mathrm{~g}$ of finely ground $P$. australis in $100 \mathrm{ml}$ of distilled water (10\%), and incubated for $24 \mathrm{~h}$. The samples have then filtered and stored until further use. ${ }^{14}$ Methanol extraction was done by macerating $10 \mathrm{~g}$ of finely ground $P$. australis in methanol for $48 \mathrm{~h}$, filtered to separate the sediment and extract, then evaporated, and ready for the antibacterial test.

\section{Antibacterial activity test}

Water and methanol extracts of $P$. australis were examined against $A$. hydropilla. This examination used disc test method $^{15}$ by immersing the sterile disc paper into each extract. After 15-30 min, the disc paper was attached to the TSA media which have been inoculated with $A$. hydropilla. Measurement of the inhibition zone was carried out after 24 $\mathrm{h}$ inoculation at $37^{\circ} \mathrm{C}$ by observing the presence of clear area formed around the disc paper.

\section{RESULTS AND DISCUSSION}

\section{Nutrient composition of $P$. australis}

Nutrient content of $P$. australis collected from Kelapa Lima coast, Kupang Bay was presented in Figure 1. P. australis contained $13.89 \%$ protein, lipid $2.66 \%$ fat, $38.15 \%$ carbohydrate, $11.21 \%$ water, and $34.58 \%$ ash (Figure 1 ).

\section{The amino acid and mineral content of $P$. australis}

P. australis containing 15 amino acids in different concentration (Table $1)$. The highest content were aspartic acid $(1.16 \% \mathrm{w} / \mathrm{w})$ and glutamic acid $(1.32 \% \mathrm{w} / \mathrm{w})$ and the lowest content were histidine $(0.12 \% \mathrm{w} / \mathrm{w})$ and methionine $(0.2 \% \mathrm{w} / \mathrm{w})$.

The mineral content of $P$. australis was $10.22 \% \mathrm{w} / \mathrm{w}$ calcium, $1.48 \% \mathrm{w} / \mathrm{w}$ potassium, and $0.125 \% \mathrm{w} / \mathrm{w}$ iron (Figure 2).

\section{Active compounds of $P$. australis}

Qualitative test of active compounds indicated that $P$. australis contained alkaloid, saponin, flavonoid, tannin steroid, and terpenoid.

\section{Antibacterial activity of $P$. australis}

The antibacterial analysis showed that water and methanol extract of $P$. australis could inhibit the growth of $A$. hydropilla. It was indicated with the presence of inhibition zones of $10.5 \mathrm{~mm}$ for water extract and 10 $\mathrm{mm}$ for methanol extract of $P$. australis (Table 3 ).

This study provided information on the nutrient content of $P$. australis, such as protein, fat, carbohydrate, water, and ash. Protein and fat content of $P$. australis found in Kelapa Lima coast, Kupang Bay, was higher than in Tidung waters, Seribu Islands, only $1.05 \%$ protein and $0.58 \%$ fat. $^{7}$ Compared with other species of macroalgae, $P$. minor found

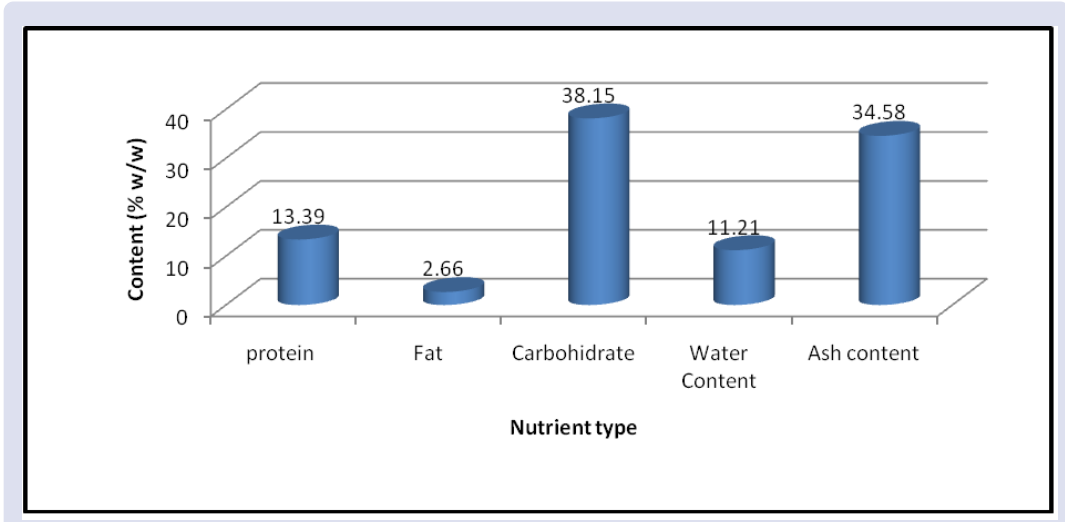

Figure 1: Nutrient content of $P$. australis found in Kelapa Lima coast, Kupang Bay.

Table 1: Amino acid content of $P$. australis found in Kelapa Lima coast, Kupang Bay.

\begin{tabular}{cc}
\hline Amino Acids & Content (\%w/w) \\
\hline Aspartic acid & 1.16 \\
Glutamic acid & 1.32 \\
Serine & 0.49 \\
Histidine & 0.12 \\
Glycine & 0.53 \\
Threonine & 0.45 \\
Arginine & 0.49 \\
Alanine & 0.73 \\
Tyrosine & 0.35 \\
Methionine & 0.20 \\
Valine & 0.62 \\
Phenylalanine & 0.55 \\
I-leucine & 0.5 \\
Leucine & 0.75 \\
Lysine & 0.28 \\
Total amino acid & 8.54 \\
\hline
\end{tabular}




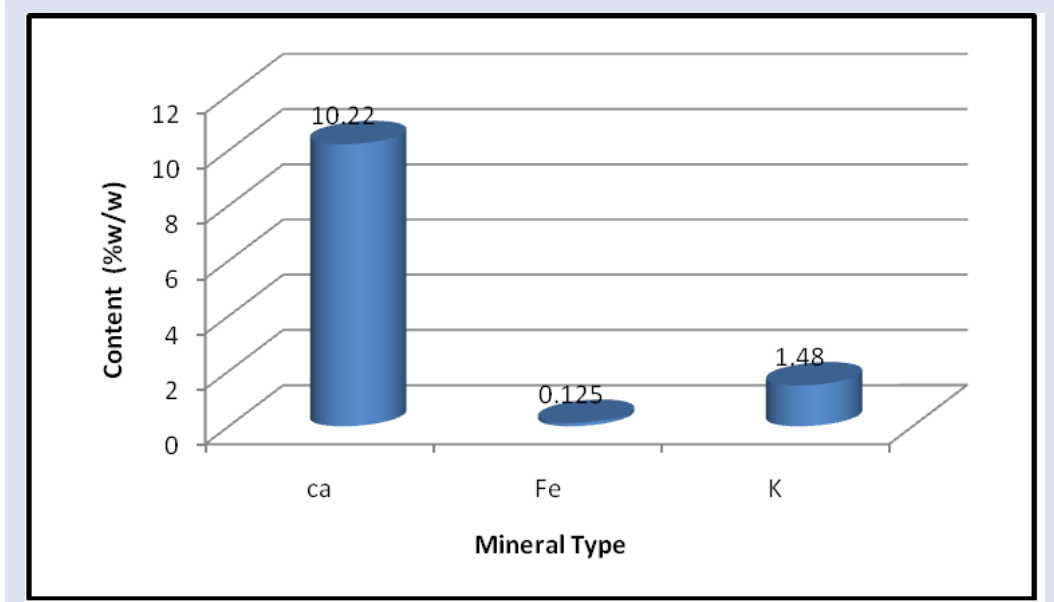

Figure 2: Calcium (Ca), ferrum ( $\mathrm{Fe}$ ), and potassium (K) in P. australis found in Kelapa Lima coast, Kupang Bay.

Table 2: Active compounds of $P$. australis in Kupang Bay waters.

\begin{tabular}{ccc}
\hline Compounds & Results & Remarks \\
\hline Alkaloid & + & White deposit formed \\
Saponin & + & Foam formation \\
Flavanoid & + & Yellow color \\
Tanin & + & Brown deposit formed \\
Terpenoid & + & Red-yellow color \\
Steroid & + & Green color formed \\
\hline
\end{tabular}

Notes: - = Undetected; + = Detected

Table 3: Antibacterial test on water extract and methanol extract of $P$. australis against bacteria A. hydropilla

\begin{tabular}{cc}
\hline Extract & Inhibition Zone $(\mathrm{mm})$ \\
\hline Methanol extract & 10 \\
Water extract & 10.5 \\
\hline
\end{tabular}

in Pahuwato waters, Gorontalo, has only $4.78 \%$ protein and $0.52 \% \mathrm{fat}^{5}$, P. gymnosprora in India contains only $5.704 \%$ protein and $0.02 \% \mathrm{fat}^{16}$, and P. tetrastomatica contains $10.5 \%$ protein and $1.14 \%$ fat. ${ }^{17}$ These differences could result from dissimilarity in harvest age and weather condition at the rearing period.?

Furthermore, carbohydrate content in $P$. australis was higher than in Tidung island, Kupang Bay, only $8.78 \%{ }^{7}$ and in Souttheast Coast of India, $14.73 \%{ }^{18}$, but lower than carbohydrate content in P. gymnospora from Sabah Malaysia, $84.54 \%{ }^{19}$ and from Tamilnadu, India, $118.14 \%{ }^{16}$, and than that in P. minor found in Pahuwato waters, Gorontalo, 41.88 $\% .^{5}$ The interspecific difference in carbohydrate content reflects that nutrients of macroalgae could be affected by species and habitat.

The water content of $P$. australis from Kelapa Lima coastal waters, Kupang Bay, was $11.21 \%$, and it is different from that reported by Fitrya $^{20}$, only $6.4 \%$, and Maharany et al. ${ }^{7}, 87.25 \%$. This difference could be influenced by light intensity and temperature at the drying process. The drying method affect the proximate content of Sargassum polycystum (brown macroalgae), including water content. Ash content of $P$. australis was high (34.58\%), if compared with P. australis collected in Tedung Island, Seribu islands, only $2.3 \% .^{7}$ It is also different from other species, such as $P$. minor, $30.53 \%{ }^{5}$, and P. tetrastomatica, $27 \% .{ }^{17}$ Higher ash content was found in P. gymnospora, $45.04 \% .^{19}$ Ash content in a material could be related with number mineral components. ${ }^{21}$ The mineral content of macroalga could be affected by the processing method as well. ${ }^{22}$ Futhermore, the level of each mineral component is determined by species, physiological factor, geographic condition, wave frequency, and the method used in mineralization. ${ }^{23}$

P. australis collected in Kupang Bay waters contained 15 amino acids with the highest content in aspartic acid, $1.16 \%$, and glutamic acid, $1.32 \%$, and the lowest in histidine, 0.12 , and methionine, $0.20 \%$. These results are not different from those in P. gymnospora from Tamildanu, India, with the highest in aspartic acid, $12.7 \%$, and glutamic acid, $13.9 \%$, and the lowest in histidine, $2.7 \%$ and methionine, $1.5 \%$, despite indifferent amount. However, Shanmuganathan and Devi ${ }^{16}$ found that P. gymnospora, in India, had different content of amino acid with the highest in glycine (0.605) and tyrosine (0.504) and the lowest in arginine (0.103). Protein content variations in macroalgae could influence the amino acid content.

The highest mineral content of $P$. australis was calcium $(10.22 \% \mathrm{w} / \mathrm{w})$, followed by potassium $(1.48 \% \mathrm{w} / \mathrm{w})$ and the lowest was iron $(0.125 \%$ $\mathrm{w} / \mathrm{w})$. A similar result is also reported by Manteu et al. ${ }^{5}$, which the highest mineral content of $P$. minor was calcium $(32.91 \mathrm{mg} / \mathrm{g})$, potassium $(26.9 \mathrm{mg} / \mathrm{g})$, and the lowest was iron $(1.00 \mathrm{mg} / \mathrm{g})$. Also, Shanmuganathan and Devi ${ }^{16}$ found that $P$. gymnospora had the highest

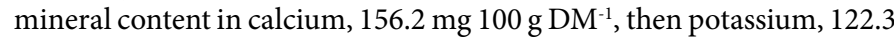
$\mathrm{mg} 100 \mathrm{~g} \mathrm{DM}^{-1}$, and the lowest in iron, $6.78 \mathrm{mg} 100 \mathrm{~g} \mathrm{DM}^{-1}$. Although the highest mineral content is found in the same mineral for the three Padina species from different localities, the concentrations are different. It means that the mineral content of Padina sp. is affected by species and habitat. 
Phytochemical analysis indicated that $P$. australis contained several compounds such as alkaloid, saponin, flavanoid, tannin, steroid, and terpenoid. The present findings are slightly different from the previous study ${ }^{19}$ that found only steroid, terpenoid, polyphenol, and saponin. P. tetrastromatica was reported holding alkaloid, terpenoid, steroid, phenol, and flavonoid, but did not contain saponin. ${ }^{24}$ P. australis contains flavanoid, tannin, and saponin ${ }^{2}$, but Maharany ${ }^{7}$ found flavonoid, phenol hydroquinone, triterpenoid, tannin, and saponin in the same species. Even though the bioactive compounds have different content, all the active compounds of Padina sp. can be used for pharmaceutics properties such as inhibit the growth of the pathogenic microorganisms.

The antibacterial activity of $P$. australis has been proved to have the ability to inhibit the growth of $A$. hydropilla in either methanol extract with an inhibition zone of $10 \mathrm{~mm}$ or water extract with the inhibition zone of $10.5 \mathrm{~mm}$ (Table 3). The ability of antibacterial activity of $P$. australis against Vibrio harveyii in fish was also reported by Gazali and Saputra ${ }^{2}$ with an inhibition zone of $12.55 \mathrm{~mm}$ at the concentration of $60 \%$. Salosso et al. ${ }^{9}$ also showed that the antibacterial activity of $P$. australis against $V$. alginoliticus as well with inhibition zone of $22 \mathrm{~mm}$ in acetone extract.

The antibacterial activity of Padina spp against pathogenic bacteria in human has also been proved by several previous researchers. Al-Enazi et al. ${ }^{25}$ revealed that the antibacterial activity of $P$. pavonica against Actinobacter baumannii, Escherichia coli, Klepsiealla pneumonia, Proteus mirabilis, Pseudomonas aururinosa, Basilus suptilis, Staphylococus aureus, S. epidermis, and Streptococus phygenes. Haryani et al. ${ }^{26}$ also showed the antibacterial activity of $P$. australis against Vibrio colera and Salmonella thypii. Other antibacterial studies were also reported by Kemer et al..$^{3}$ on P. australis from Nain island, North Sulawesi, against Yersinia enterocolitica and Proteus stuarti, Nuzul et al. ${ }^{10}$ on Padina sp, from Sorido coast, Biak, against Staphylococcus aureus and Shigella dysentriae, and Maheswari et al..$^{24}$ on P. tetrastomatica from Tamil Nadu, India, against Salmonella typhy, Vibrio cholera, Shigella flexnery, and Proteus mirablis.

\section{CONCLUSION}

This study revealed that $P$. australis produced antibacterial effect against A. hydropilla which could be potential for further development.

\section{REFERENCES}

1. Da costa JF, Merdekawati W, Out FR. Proximate analysis, antioxidant activity, and pigment composition of U/va lactuca $L$ from Kukup coastal waters. Jurna Teknologi Pangan dan Gizi. 2018;17(1):1-17.

2. Gazali M, Saputra E. Antibacterial potential screening of Padina audtralis Hauck extract on the bacteria Vibrio harveyii. Jurnal Perikanan Tropis. 2016;3(2):163-75.

3. Kemer K, Paransa DSJ, Rumengan AP, Mantiri DMH. Antibacterial of several extracts of brown algae. Jurnal LPPM Bidang Sains dan Teknologi. 2015;2:7381.

4. Puasa ES, Mantiri DMH, Rumengan A. Antibacterial analysis of algae Padina australis Hauck in Totok Bay and Blongko waters. Jurnal Pesisir dan Laut Tropis. 2018;1(1):14-20.
5. Manteu SH, Nurjanah, Nurhayati T. Characteristics of brown algae (Sargassum policystum and Padina minor) from Pohuwato waters, Gorontalo Province. JPHPI. 2018;21(3):396-405

6. El Shafay SM, Ali SS, El-Sheekh MM. Antimicrobial activity of some seaweeds species from Red sea, against multidrug resistant bacteria. Egypt. J Aquat. Res. 2016;42(1):65-74.

7. Maharany F, Nurjannah, Suwandi R, Anwar E, Hidayat T. Bioactive compounds of seaweed Padina australis and Euchema cottonii as raw material of sunscreen cream. Jurnal Pengolahan Hasil Perikanan Indonesia. 2017;20(1):10-17.

8. Santoso J, Gunji S, Yoshi-Stark Y, Suzuki T. Mineral content of Indonesian seaweed and mineral solubility affected by basic cooking. Food Sci Technol Res. 2006;12(10):59-66.

9. Salosso Y, Prajitno A, Abadi AL, Aulanni'am. Study on potential of Padina australis as natural antibacterial in bacteria Vibrio alginolitycus control in humpback grouper (Cromileptes altivelis) culture. Jurnal Bahan Alam Indonesia. 2011;7:365-9.

10. Nuzul P, Lantang D, Dirgantara S. Antibacterial activity test of brown algae Padina sp from Sorido coast, Biak, on the bacteria Staphylococcus aureus and Shigella dysentriae. Pharm Med J. 2018;1(1):16-25.

11. Salosso $Y$, Jasmanindar $Y$. Diversity of brown macroalgae in Kupang Bay waters and alginate content potential and its phytochemistry. AACL Bioflux. 2018;11(3):598-605.

12. AOAC (Association of Official Analytical Chemist). Official Method of Analysis of the Association of Official Analytical of Chemist. Arlington: The Association of Official Analytical Chemist, Inc., 684-690; 2005.

13. Hanani E. Phytochemical Analysis. Jakarta: Penerbit buku Kedokteran, EGC, p. 262-269; 2014

14. Salosso Y, Jasmanindar Y. Potential of Patikan Kerbau (Euphorbia hirta) as antibacterial on Aeromonas hydropilla and Vibrio alginolitycus in Fish Culture. Aquat Sci Technol. 2014;2(1):63-72.

15. Pratiwi ST. Pharmacetical Microbiology. Jakarta: Erlangga Medical Series, 237239;2008.

16. Shanmuganathan B, Devi KP. Evaluation of the nutritional profile and antioxidant and anti-cholinesterase activities of Padina gymnospora (Phaeophyceae). Eur J Phycol. 2016;51(4):482-90.

17. Felix N, Brindo RA. Effects of raw and fermented seaweed, Padina tetrastomatica on the growth and food conversion of giant freshwater prawn Microbrachium rosenbergii. Int. J. Fish. Aquat. Stud. 2014;1(4):108-13.

18. Manivannan K, Thirumaran G, Devi GK, Anantharaman P, Balasubramanian, T., 2009 Proximate composition of different group of seaweeds from Vedala coastal water (Gulf of Mannar): Southeast Coast of India. Middle-East J Sci Res. 4(2):72-7.

19. Ahmad $H$, Sulaiman MR, Saiman W, Fook YC, Matanjum P. Proximate compositions and total phenolic contents of selected edible seaweed from semporna, Sabah Malaysia. Borneo Sci. 2012;31:85-96.

20. Fitrya F. Examination of alga Padina australis Hauck sample characteristics (Dictyotaceae). Journal Penelitian Sains. 2010;13(3):46-9.

21. Ratana-arporn $P$, Chirapart $A$. Nutritional evaluation of tropical green seaweeds Caulerpa lentillifera and Ulva reticulate. Kasetsart J (Nat. Sci.). 2006;40:75-83.

22. Ruperez P. Mineral content of edible seaweed. Food Chem. 2002;79(1):23-6.

23. Mabeau S, Fleurence J. Seaweed in Food products: Biochemical and Nutritional Aspects. Trends Food Sci. Technol. 1993;4(4):103-7.

24. Maheswari MU, Reena A, Sivaraj C. GC-MS Analysis, antioxidant and antibacterial, activity of the Brown Algae, Padina tetrastromatica. Int J Pharm Sci Res. 2018;9(1):298-304

25. Al-Enazi NM, Awaad AS, Zain ME, Alqasoumi SI. Antimicrobial, antioxidant and anticancer activities of Laurencia catarinensis, Laurencia majuscule and Padina pavonica extracts. Saudi Pharm J. 2018;26(1):44-52.

26. Haryani TP, Triastinurmiatiningsih AW. Effectivity of Padina australis extract as antibacterial Vibrio cholera and Salmonella typhii. Ekologia. 2015;15(2):16-20. 


\section{GRAPHICAL ABSTRACT}

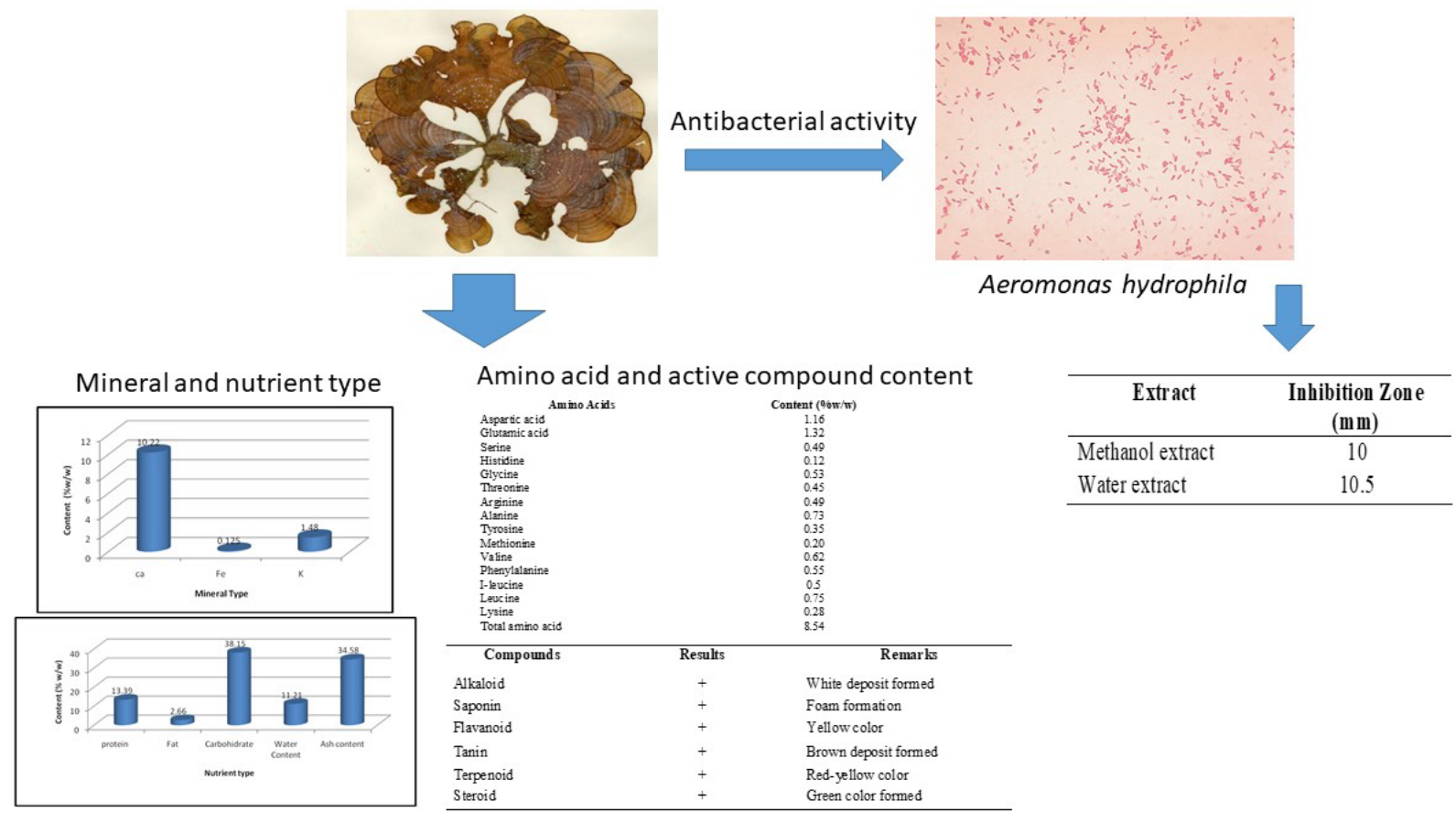

\section{ABOUT AUTHORS}

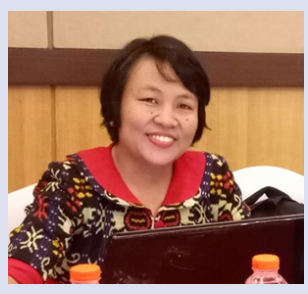

Yuliana Salosso received her doctoral degree at Brawijaya University, Malang, Indonesia. She is currently a lecturer at Study Program of Aquaculture, Faculty of Fisheries and Marine Science, Nusa Cendana University, Indonesia. Area of expertise are aquaculture research especially fish disease.

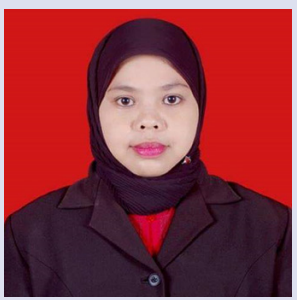

Siti Aisiah received her doctoral degree at Faculty of Fisheries and Marine Science, Brawijaya University, Indonesia. She is currently a lecturer at Department of Aquaculture, Lambung Mangkurat University, Indonesia. Her expertise is about fisheries health and aquaculture management.

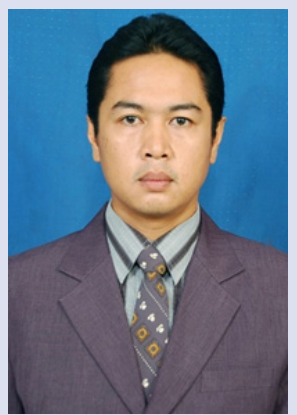

Lumban Nauli Lumban Toruan received his magister degree at Bogor Agricultural University, Indonesia. He is a lecturer at Study Program of Aquatic Resource Management, Faculty of Fisheries and Marine Science, Nusa Cendana University, Indonesia. His research is focused on marine ecology, biological oceanography, chemical oceanography, tropical oceanography, and foraminifera. 


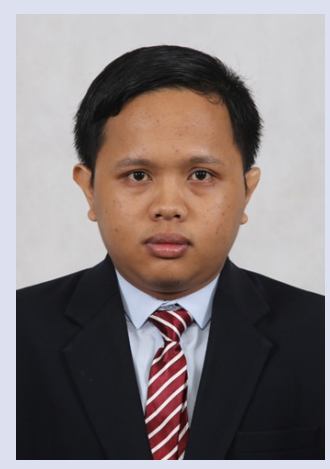

Wesly Pasaribu received his magister degree at Bogor Agricultural University, Indonesia. He is currently a lecturer at Department of Aquaculture, Faculty of Fisheries and Marine Science, Nusa Cendana University, Indonesia. His expertise is about aquaculture research.

Cite this article: Salosso Y, Aisiah S, Toruan LNL, Pasaribu W. Nutrient Content, Active Compound, and Antibacterial Activity of Padina australis against Aeromonas hydropillar. Pharmacogn J. 2020;12(4):771-6. 